\title{
The Isotopic Abundance Ratio of Consciousness Energy Treated L-Tryptophan Using LC-MS Spectrometry
}

Keywords: L-tryptophan; Biofield Energy; The Trivedi Effect ${ }^{\circledR}$; Consciousness Energy Treatment; Isotopic abundance

\begin{abstract}
L-tryptophanis an essential amino acid, essential for normal growth of child and adults, protein synthesis, precursor of serotonin, melatonin and niacin. The research work was designed to investigate the impact of the Trivedi Effect ${ }^{\circledR}$ - Consciousness Energy Treatment on the structural properties and the isotopic abundance ratio of L-tryptophan using liquid chromatography - mass spectrometry analytical technique. The L-tryptophan sample was divided into Control and the Biofield Energy Treated tryptophan. The treated tryptophan sample received Biofield Energy Treatment (the Trivedi Effect ${ }^{\circledR}$ ) remotely for $\sim 3$ minutes by $\mathrm{Mr}$. Mahendra Kumar Trivedi, who was located in the USA, while the test samples were located in the research laboratory in India. The mass spectra of both the tryptophan samples at retention time 2 minutes exhibited the molecular ion mass peak adduct with hydrogen ion a $\mathrm{m} / \mathrm{z} 205\left(\mathrm{C}_{11} \mathrm{H}_{13} \mathrm{~N}_{2} \mathrm{O}_{2}^{+}\right)$along with low molecular fragmented mass peaks at $\mathrm{m} / \mathrm{z} 188$ and 102 for $\mathrm{C}_{11} \mathrm{H}_{12} \mathrm{~N}_{2} \mathrm{O}^{2+}$ and $\mathrm{C}_{8} \mathrm{H}_{6}{ }^{+}$, respectively. The isotopic abundance ratio of $\mathrm{P}_{\mathrm{M+1}} / \mathrm{P}_{\mathrm{M}}\left({ }^{2} \mathrm{H} /{ }^{1} \mathrm{H}\right.$ or ${ }^{13} \mathrm{C} /{ }^{12} \mathrm{C}$ or $\left.{ }^{15} \mathrm{~N} /{ }^{14} \mathrm{Nor}{ }^{17} \mathrm{O} /{ }^{16} \mathrm{O}\right)$ in the Treated L-tryptophan was significantly increased by $21.89 \%$ compared with the Control sample. Therefore, ${ }^{13} \mathrm{C},{ }^{2} \mathrm{H},{ }^{15} \mathrm{~N}$, and ${ }^{17} \mathrm{O}$ contributions from $\mathrm{C}_{11} \mathrm{H}_{13} \mathrm{~N}_{2} \mathrm{O}_{2}^{+}$to $\mathrm{m} / \mathrm{z} 206.08$ in the Treatedtryptophan was increased significantly compared to the Control sample. The change in the isotopic abundance might be due to the modification in nuclei possibly through the interference of neutrino particles with the help ofthe Trivedi Effect ${ }^{\circledR}$-Consciousness Energy Treatment. The increased isotopic abundance ratio of the Treated tryptophan may increase the intra-atomic bond strength, increase its stability, and shelflife. The Biofield Energy Treated tryptophan might have increased the stability and shelf-life compared to the Control sample. The Treated tryptophan would be more stable in the nutraceutical, and pharmaceutical formulations, which would be advantageous for the prevention and treatment of pellagra, depression, kynurenine. It could also maintain the normal label of tryptophan and avoid increase of its metabolite, lower the neurotoxin and a metabotoxin behavior, glutaric aciduria type I disorder, eosinophilia-myalgia syndrome, etc. The Treated L-tryptophan would be advantageous for the improvement of yield, productivity, and quality of crops and other plants.
\end{abstract}

\section{Introduction}

L-tryptophanis an essential amino acid, necessary for normal growth of child and adults, protein synthesis, precursor of serotonin, melatonin, and niacin. It is also the precursor of indole alkaloids and auxins plant hormone $[1,2]$. It increases the production of serotonin in the body $[1,3]$. It is obtained from the foods and supplements. Food sources of tryptophan are red meat, eggs, fish, poultry, brown rice, soybeans, oats, dried dates, milk, chocolate, yogurt, cottage cheese, sesame, peanuts, pumpkin seeds, chickpeas, almonds, sunflower seeds, spirulina, etc. [1,2]. Hartnup's disease, improper diet, high maize diets, fructose mal absorption, etc. are the main cause for the reduced levels of tryptophan in the body. Tryptophan deficiency may cause

\section{Journal of}

Nutrition and Health

\author{
Trivedi MK ${ }^{1}$, Branton A $\mathbf{A}^{1}$, Trivedi $\mathbf{D}^{1}$ and Jana $\mathbf{S}^{\mathbf{2}^{*}}$ \\ ${ }^{\prime}$ Trivedi Global, Inc., Henderson, USA \\ ${ }^{2}$ Trivedi Science Research Laboratory Pvt. Ltd., Thane, India
}

\section{*Address for Correspondence}

Jana S, Trivedi Science Research Laboratory Pvt. Ltd., Thane (W), Maharashtra, India. Tel: 91-022-25811234; Email: publication@trivedisrl.com

Submission: 8 March, 2021

Accepted: 15 April, 2021

Published: 23 April, 2021

Copyright: () 2020 Trivedi MK, et al. This is an open access article distributed under the Creative Commons Attribution License, which permits unrestricted use, distribution, and reproduction in any medium, provided the original work is properly cited.

pellagra; the other deficiency diseases are depression and kynurenine. If the label of tryptophan and its metabolite increase, it can behave like a neurotoxin and a metabotoxin, eosinophilia-myalgia syndrome, glutaric aciduria type I disorder, create an incurable and sometimes fatal flu-like neurological condition, etc. [1, 2, 5-8]. L-tryptophan is slightly soluble in water, very slightly soluble in alcohol, practically insoluble in ether and chloroform. Heat decompose it and emits toxic fumes of nitric oxide [1].

Physicochemical properties of L-tryptophanarevery important for the pharmaceutical and nutraceutical formulations and other industrial applications [9]. The Trivedi Effect'-Consciousness Energy Treatment have the amazing capabilities to transform the properties of many living and non-living object(s) [10-14]. The Trivedi Effect is a natural and only scientifically proven phenomenon in which an expert can harness this inherently intelligent energy from the Universe and transmit it anywhere on the planet through the possible mediation of neutrinos [15]. Every living organism possesses a unique infinite, para-dimensional electromagnetic energy field surrounding the body known as the Biofield Energy. The Biofield Energy Healers can harness the energy from the "Universal Energy Field" and can transmit into any living or non-living object(s), which is known as the Biofield Energy Treatment. There are several Biofield based Energy Therapies that are used nowadays against various disease conditions [16-18]. The Biofield Energy therapy has been recognized worldwide as a Complementary and Alternative Medicine health care approach by National Center of Complementary and Integrative Health with other therapies, medicines and practices such as traditional Ayurveda, Chinese herbs and medicines, naturopathy, homeopathy, yoga, meditation, Qi Gong, Tai Chi, acupressure, acupuncture, healing touch, Reiki, hypnotherapy, cranial sacral therapy, etc. [19]. Such therapies have been well accepted by most of the U.S.A. population with advantages [20]. The Trivedi Effect- Consciousness Energy Treatment also reported with significant results altering the intrinsic properties of metals, organic compounds, ceramics, polymers, microbes, and cancer cell line; improved yield, productivity, and quality of crops, improved bioavailability of pharmaceutical and nutraceutical compounds, and altered the isotopic abundance ratio 


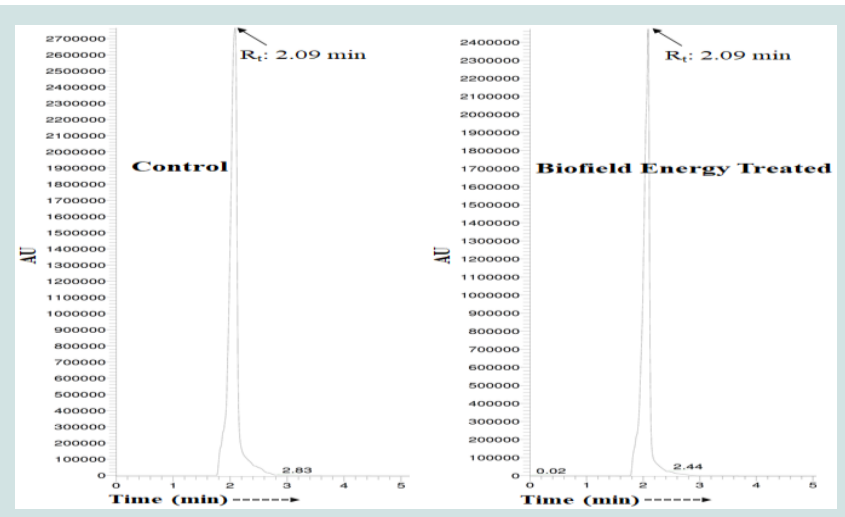

Figure 1: Liquid chromatograms of the Control and the Biofield Energy Treated L-tryptophan.

\section{[21-31].}

Study of the natural stable isotope ratio analysis has many applications in the different field to understand the isotope effects resulting from the alterations of the isotopic composition [32-34]. Gas chromatography - mass spectrometry (GC-MS) and liquid chromatography - mass spectrometry (LC-MS), are the widely used sophisticated analytical techniques for the analysis of isotope ratio with sufficient precision [33]. The Consciousness Energy Treatment could be an economical approach to obtain a better desirable L-tryptophan with improved physicochemical properties for the supplements, nutraceutical, and pharmaceutical formulations. Therefore, this study was designed and evaluated the impact ofthe Trivedi Effect on L-tryptophan usingLC-MS for the structural characterization and the isotopic abundance ratio of $\mathrm{P}_{\mathrm{M}+1} / \mathrm{P}_{\mathrm{M}}\left({ }^{2} \mathrm{H} /{ }^{1} \mathrm{H}\right.$ or ${ }^{13} \mathrm{C} /{ }^{12} \mathrm{C}$ or ${ }^{15} \mathrm{~N} /{ }^{14} \mathrm{~N}$ or ${ }^{17} \mathrm{O} /{ }^{16} \mathrm{O}$ ) compared to the Control sample.

\section{Materials and Methods}

\section{Chemicals and Reagents}

L-tryptophan(> 99\%) was purchased from Alfa Aesar, India and other chemicals used in the experiment were of analytical grade purchased in India too.

\section{Consciousness Energy Treatment Strategies}

The test compound L-tryptophan was divided into two parts, among which, one part did not receive the Biofield Energy Treatment and considered as the Controlsample. The second part of the test compound received the Energy of Consciousness Treatment remotely for $\sim 3$ minutes through the Unique Energy Transmission process by Mr. Mahendra Kumar Trivedi, who was located in the USA, while the test samples were located in the research laboratory in India, and it was labelled as the Biofield Energy Treated L-tryptophan. On the other hand, the Control sample was subjected to "sham" healer, who did not have any knowledge about the Biofield Energy Treatment, under the similar laboratory conditions. After that, the Biofield Energy Treated and un-treated L-tryptophan samples were kept in sealed conditions and characterized using LC-MS analytical technique.

\section{Characterization}

Liquid Chromatography-Mass Spectrometry (LC-MS) Analysis and Calculation of Isotopic Abundance Ratio

The liquid chromatography-mass spectrometric analysis of the Control and the Biofield Energy Treated L-tryptophan was carried out with the help of LC-MS Thermo Fisher Scientific, the USA equipped with an ion trap detector connected with a triple-stage quadrupole mass spectrometer. The column used here was a reversed phase Thermo Scientific Synchronis C18 (Length-250 mm X ID 4.6 $\mathrm{mm} X 5$ micron), maintained at $25^{\circ} \mathrm{C}$. The diluent used for the sample preparation was methanol. The L-tryptophan solution injection volume was $10 \mu \mathrm{L}$ and the analyte was eluted using acetonitrile (80\%) $+0.1 \%$ formic acid (20\%) pumped at a constant flow rate of $1 \mathrm{~mL} / \mathrm{min}$. Chromatographic separation was achieved using gradient condition and the total run time was $10 \mathrm{~min}$. Peaks were monitored at $278 \mathrm{~nm}$ using the PDA detector. Mass spectrometric analysis was performed under ESI +ve ion mode. The total ion chromatogram, peak area\% and mass spectrum of the individual peak which was appeared in LC along with the full scan $(\mathrm{m} / \mathrm{z} 50-400)$ were recorded. The total ion chromatogram and mass spectrum of the individual peak (appeared in LC-MS) were recorded.

The natural abundance of each isotope $(\mathrm{C}, \mathrm{H}, \mathrm{N}$, and $\mathrm{O})$ can be predicted from the comparison of the height of the isotope peak with respect to the base peak. The values of the natural isotopic abundance of the common elements are obtained from the literature [35-37]. The LC-MS based isotopic abundance ratio $\left(\mathrm{P}_{\mathrm{M}+1} / \mathrm{P}_{\mathrm{M}}\right)$ for the Control andthe Biofield Energy Treated L-tryptophan $\left(\mathrm{C}_{11} \mathrm{H}_{13} \mathrm{~N}_{2} \mathrm{O}_{2}^{+}\right)$was calculated.

Percentage (\%) change in isotopic abundance ratio $=\left[\left(\mathrm{IAR}_{\text {Treated }}-\right.\right.$ $\left.\left.\left.\mathrm{IAR}_{\text {Control }}\right) / \mathrm{IAR}_{\text {Control }}\right) \times 100\right]$

Where $\mathrm{IAR}_{\text {Treated }}=$ isotopic abundance ratio in the Treated sample and $\mathrm{IAR}_{\mathrm{Control}}=$ isotopic abundance ratio in the Control sample.

\section{Results and Discussion}

\section{Liquid Chromatography-Mass Spectrometry (LC-MS)}

Both the samples of L-tryptophan showed a single prominent peakat retention time $\left(\mathrm{R}_{\mathrm{t}}\right)$ of 2.1 minutes in the LC-SM chromatograms (Figure 1). This result indicated that both the samples are pure and have similar polarity.

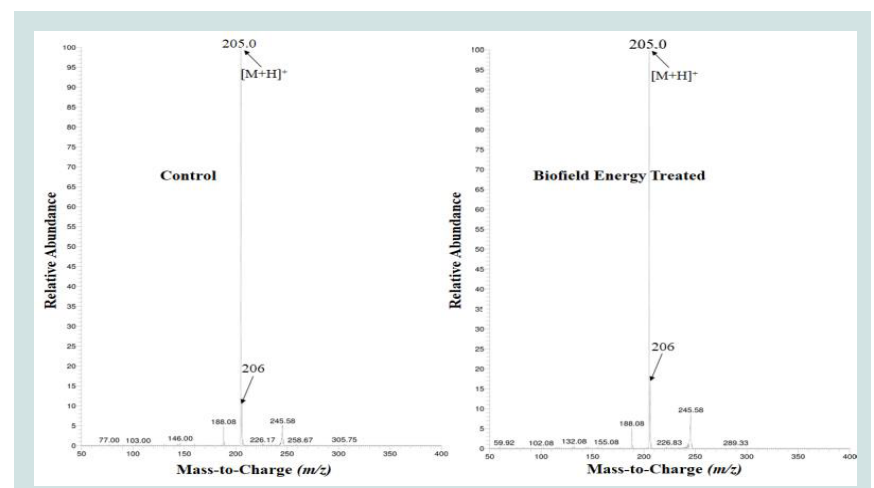

Figure 2: Mass spectra of the Control and the Biofield Energy Treated L-tryptophanat $R_{t} 2.1$ minutes. 


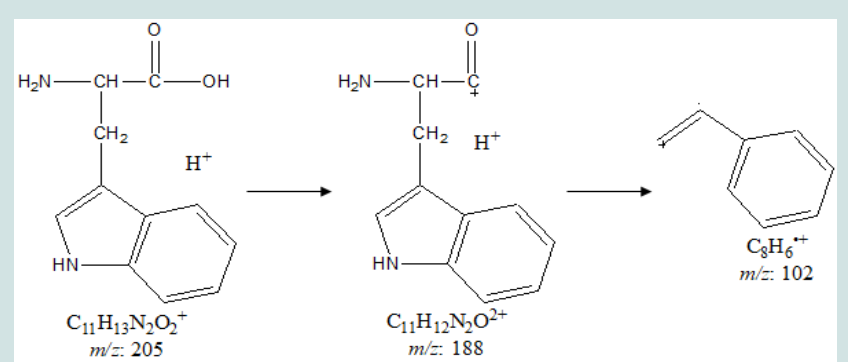

Figure 3: Proposed fragmentation pattern of L-tryptophan.

Table 1: LC-MS based isotopic abundance analysis results in the Biofield Energy Treated L-tryptophan compared to the Control sample.

\begin{tabular}{|l|l|l|}
\hline Parameter & $\begin{array}{l}\text { Control } \\
\text { sample }\end{array}$ & $\begin{array}{l}\text { Biofield Energy Treated } \\
\text { sample }\end{array}$ \\
\hline $\mathrm{P}_{\mathrm{M}}$ at $m / z 205(\%)$ & 100.00 & 100.00 \\
\hline $\mathrm{P}_{M+1}$ at $m / z 206(\%)$ & 10.60 & 12.92 \\
\hline $\mathrm{P}_{M+1} / \mathrm{P}_{\mathrm{M}}$ & 0.11 & 0.13 \\
\hline $\begin{array}{l}\% \text { Change of isotopic abundance ratio } \\
\left(\mathrm{P}_{\mathrm{M}+1} / \mathrm{P}_{\mathrm{M}}\right) \\
\text { sample }\end{array}$ & & 21.89 \\
\hline
\end{tabular}

The mass spectra of both the samples of L-tryptophan are presented in Figure 2. The mass spectra of both the samples at $R_{t}$ of 2 minutes exhibited the presence of the molecular ion of L-tryptophan adduct with hydrogen ion at $\mathrm{m} / z 205.08$ (calcd for $\mathrm{C}_{11} \mathrm{H}_{13} \mathrm{~N}_{2} \mathrm{O}_{2}^{+}$, 205.1), along with low molecular fragmented mass peaks at $\mathrm{m} / z 188$ and 102 for $\mathrm{C}_{11} \mathrm{H}_{12} \mathrm{~N}_{2} \mathrm{O}^{2+}$ and $\mathrm{C}_{8} \mathrm{H}_{6}^{+}$, respectively (Figures 3). The fragmentation pattern of the experimental data was well supported by the published literature data [38]. The study confirmed the structure of the sample as L-tryptophan.

\section{Isotopic Abundance Ratio Analysis}

The Control and the Biofield Energy Treated samples showed the molecular ion mass peak at $m / z 205.08$ (calcd for $\mathrm{C}_{11} \mathrm{H}_{13} \mathrm{~N}_{2} \mathrm{O}_{2}^{+}$, 205.1 ) with $100 \%$ relative abundance in the spectra. The theoretical calculation of isotopic peak $\mathrm{P}_{\mathrm{M}+1}$ for the protonated L-tryptophan presented as below:

$\mathrm{P}\left({ }^{13} \mathrm{C}\right)=\left[(11 \times 1.1 \%) \times 100 \%\right.$ (the actual size of the $\mathrm{M}^{+}$peak $\left.)\right] /$ $100 \%=12.1 \%$

$$
\begin{aligned}
\mathrm{P}\left({ }^{2} \mathrm{H}\right) & =[(13 \times 0.015 \%) \times 100 \%] / 100 \%=0.195 \% \\
\mathrm{P}\left({ }^{15} \mathrm{~N}\right) & =[(2 \times 0.4 \%) \times 100 \%] / 100 \%=0.8 \% \\
\mathrm{P}\left({ }^{17} \mathrm{O}\right) & =[(2 \times 0.04 \%) \times 100 \%] / 100 \%=0.08 \% \\
\mathrm{P}_{\mathrm{M}+1} \text { i.e. } & { }^{13} \mathrm{C},{ }^{2} \mathrm{H},{ }^{15} \mathrm{~N}, \text { and }^{17} \mathrm{O} \text { contributions from } \mathrm{C}_{11} \mathrm{H}_{13} \mathrm{~N}_{2} \mathrm{O}_{2}{ }^{+} \text {to } \\
m / z 206.08 & =13.18 \%
\end{aligned}
$$

The calculated isotopic abundance of $\mathrm{P}_{\mathrm{M}+1}$ value13.18\% was close to the experimental values (Table 1). From the above calculation, it has been found that ${ }^{13} \mathrm{Cand}{ }^{15} \mathrm{~N}$ have the major contribution to $\mathrm{m} / \mathrm{z}$ 206.

The LC-MS based isotopic abundance ratio analysis $\mathrm{P}_{\mathrm{M}}$ andP $\mathrm{M}_{\mathrm{M}+1}$ for L-tryptophan near $\mathrm{m} / z 205$ and 206, respectively of the Control and the Biofield Energy Treated samples, which were obtained from the observed relative peak intensities of $\left[\mathrm{M}^{+}\right]$and $\left[(\mathrm{M}+1)^{+}\right]$peaks, respectively in the mass spectra (Table 1 ). The isotopic abundance ratio of $\mathrm{P}_{\mathrm{M}+1} / \mathrm{P}_{\mathrm{M}}\left({ }^{2} \mathrm{H} /{ }^{1} \mathrm{H}\right.$ or ${ }^{13} \mathrm{C} /{ }^{12} \mathrm{C}$ or $\left.{ }^{15} \mathrm{~N} /{ }^{14} \mathrm{Nor}{ }^{17} \mathrm{O} /{ }^{16} \mathrm{O}\right)$ in Consciousness Energy Treated L-tryptophan was significantly increased by $21.89 \%$ compared to the Control sample (Table 1). Thus, the ${ }^{13} \mathrm{C},{ }^{2} \mathrm{H},{ }^{15} \mathrm{~N}$, and ${ }^{17}$ Ocontributions from $\mathrm{C}_{11} \mathrm{H}_{13} \mathrm{~N}_{2} \mathrm{O}_{2}{ }^{+}$to $m / z 206$ in the Biofield Energy Treated sample was significantly increased compared to the Control sample.

$\mathrm{P}_{\mathrm{M}}$ : the relative peak intensity of the parent molecular ion $\left[\mathrm{M}^{+}\right] ; \mathrm{P}_{\mathrm{M}+1}$ : the relative peak intensity of the isotopic molecular ion $\left[(\mathrm{M}+1)^{+}\right], \mathrm{M}$ : mass of the parent molecule.

The isotopic abundance ratio of $\mathrm{P}_{\mathrm{M}+1} / \mathrm{P}_{\mathrm{M}}\left({ }^{2} \mathrm{H} /{ }^{1} \mathrm{H}\right.$ or ${ }^{13} \mathrm{C} /{ }^{12} \mathrm{C}$ or ${ }^{15} \mathrm{~N} /{ }^{14} \mathrm{~N}$ or ${ }^{17} \mathrm{O} /{ }^{16} \mathrm{O}$ ) in the Biofield Energy Treated L-tryptophan was significantly increased compared to the Control sample. The Trivedi Effect -Consciousness Energy Treatment might have the impact on nuclei of L-tryptophan possibly via the mediation of neutrino particles would be the solid cause behind the change in the isotopic abundance ratio $[15,30,31]$. A neutrino is an elementary particle that interacts only via the weak subatomic force and gravity. The properties to change identities which are only possible if the neutrinos possess mass and have the ability to interchange their phase from one phase to another internally. Thus, the neutrinos have the ability to interact with protons and neutrons in the nucleus, which indicated a close relation between neutrino and the isotope formation $[33,34]$. The altered isotopic composition in molecular level of the Consciousness Energy Treated L-tryptophan might have altered the neutron to proton ratio in the nucleus. The Biofield Energy Treated L-tryptophan with increased stable isotopic abundance ratio, might have changed the physicochemical properties with higher force constant with the atoms of the L-tryptophan. The Biofield Energy Treated L-tryptophan with improved physicochemical properties would be more desirable for the supplements, nutraceutical, and pharmaceutical formulations, which would be advantageous for the prevention and treatment of pellagra, depression, kynurenine. It could also maintain the normal label of tryptophan and avoid increase of its metabolite, lower the neurotoxin and a metabotoxin behavior, glutaric aciduria type I disorder, eosinophilia-myalgia syndrome, incurable and sometimes fatal flu-like neurological condition, etc. Tryptophan is the precursor for the plant hormones like indole alkaloids and auxins. Thus, the Biofield Energy Treated L-tryptophan would be advantageous for the improvement of yield, and productivity of crops.

\section{Conclusions}

The Trivedi Effect'-Consciousness Energy Treatment showed the significant impact on the isotopic abundance ratioofL-tryptophan. The mass spectra of both the tryptophan samples at retention time 2 minutes exhibited the molecular ion mass peak adduct with hydrogen ion at $\mathrm{m} / z 205$ along with low molecular fragmented mass peaks at $\mathrm{m} / z 188$ and 102 for $\mathrm{C}_{11} \mathrm{H}_{12} \mathrm{~N}_{2} \mathrm{O}^{2+}$ and $\mathrm{C}_{8} \mathrm{H}_{6}^{+}$, respectively. The isotopic abundance ratio of $\mathrm{P}_{\mathrm{M}+1} / \mathrm{P}_{\mathrm{M}}\left({ }^{2} \mathrm{H} /{ }^{1} \mathrm{H}\right.$ or ${ }^{13} \mathrm{C} /{ }^{12} \mathrm{C}$ or $\left.{ }^{15} \mathrm{~N} /{ }^{14} \mathrm{Nor}{ }^{17} \mathrm{O} /{ }^{16} \mathrm{O}\right)$ in the Biofield Energy Treated L-tryptophan was significantly increased by $21.89 \%$ compared with the Control sample. Therefore, ${ }^{13} \mathrm{C},{ }^{2} \mathrm{H},{ }^{15} \mathrm{~N}$, and ${ }^{17} \mathrm{O}$ contributions from $\mathrm{C}_{11} \mathrm{H}_{13} \mathrm{~N}_{2} \mathrm{O}_{2}{ }^{+}$to $m / z 206.08$ in the Biofield Energy Treated tryptophan was increased significantly compared to the Control sample. The change in the isotopic abundance might be 
Citation: Trivedi MK, Branton A, Trivedi D, Jana S. The Isotopic Abundance Ratio of Consciousness Energy Treated L-Tryptophan Using LC-MS Spectrometry. J Nutri Health. 2021;7(1): 05.

due to the modification in nuclei possibly through the interference of neutrino particles with the help of the Trivedi Effect-Consciousness Energy Treatment. The increased isotopic abundance ratio of the Biofield Energy Treated tryptophan may increase the intra-atomic bond strength, increase its stability, and shelf-life. The Biofield Energy Treated tryptophan might have increased the stability and shelf-life compared to the Control sample. The Treated tryptophan would be more stable in the nutraceutical, and pharmaceutical formulations, which would be advantageous for the prevention and treatment of pellagra, depression, kynurenine. It could also maintain the normal label of tryptophan and avoid increase of its metabolite, lower the neurotoxin and a metabotoxin behavior, eosinophiliamyalgia syndrome, glutaric aciduria type I disorder, incurable and fatal flu-like neurological condition, etc. The Treated L-tryptophan would be advantageous for the improvement of yield, productivity, and quality of crops and other plants.

\section{References}

1. L-Tryptophan 2020.

2. Tryptophan. Retrieved 02 May 2020.

3. Timothy C, Birdsall (1998) 5-Hydroxytryptophan: A Clinically-Effective Serotonin Precursor. Altern Med Rev 3: 271-280.

4. Joanne H "USDA National Nutrient Database for Standard Reference, Release 22". Nutrient Data Laboratory, Agricultural Research Service, United States Department of Agriculture 2020.

5. Ledochowski M, Widner B, Murr C, Sperner-Unterweger B, Fuchs D (2001) Fructose malabsorption is associated with decreased plasma tryptophan. Scand J Gastroenterol 36: 367-371.

6. Ledochowski M, Sperner-Unterweger B, Widner B, Fuchs D (1998) Fructose malabsorption is associated with early signs of mental depression. Eur $\mathrm{J}$ Med Res 3: 295-298.

7. Allen JA, Peterson A, Sufit R, Hinchcliff ME, Mahoney JM, et al. (2011) Post-epidemic eosinophilia-myalgia syndrome associated with L-tryptophan. Arthritis Rheum 63: 3633-3639.

8. Pusti S, Das N, Nayek K, Biswas S (2014) A treatable neurometabolic disorder: Glutaric aciduria type 1. Case Rep Pediatr. 2014: 256356.

9. Yadav AV, Yadav VB (2008) Designing of pharmaceuticals to improve physicochemical properties by spherical crystallization technique. Journal of Pharmacy Research 1: 105-110.

10. Trivedi MK, Branton A, Trivedi D, Nayak G, Gangwar M, et al. (2015) Effect of biofield energy treatment on chlorophyll content, pathological study, and molecular analysis of cashew plant (Anacardium occidentale L.) Journal of Plant Sciences 3: 372-382.

11. Sances F, Flora E, Patil S, Spence A, Shinde V (2013) Impact of biofield treatment on ginseng and organic blueberry yield. AGRIVITA, Journal of Agricultural Science 35: 22-29.

12. Trivedi MK, Branton A, Trivedi D, Shettigar H, Nayak G, et al. (2015) Assessment of antibiogram of multidrug-resistant isolates of Enterobacter aerogenes after biofield energy treatment. J Pharma Care Health Sys 2: 145

13. Trivedi MK, Branton A, Trivedi D, Nayak G, Sethi KK, Jana S (2016) Isotopic abundance ratio analysis of biofield energy treated indole using gas chromatography-mass spectrometry. Science Journal of Chemistry 4: 41-48.

14. Trivedi MK, Nayak G, Patil S, Tallapragada RM, Latiyal O, et al. (2015) Impact of biofield treatment on atomic and structural characteristics of barium titanate powder. Ind Eng Manage 4: 166

15. Trivedi MK, Mohan TRR (2016) Biofield Energy Signals, Energy Transmission and Neutrinos, American Journal of Modern Physics 5: 172-176.

16. Rubik B, Muehsam D, Hammerschlag R, Jain S (2015) Biofield Science and
Healing: History, Terminology, and Concepts. Global Advances in Health and Medicine 4: 8-14

17. Warber SL, Cornelio D, Straughn, J, Kile G (2004) Biofield energy healing from the inside. J Altern Complement Med 10: 1107-1113.

18. Movaffaghi Z, Farsi M (2009) Biofield therapies: biophysical basis and biological regulations? Complement Ther Clin Pr 15: 35-37.

19. Koithan M (2009) Introducing complementary and alternative therapies. J Nurse Pract 5: 18-20.

20. Barnes PM, Bloom B, Nahin RL (2008) Complementary and alternative medicine use among adults and children: United States, 2007. Natl Health Stat Report 12: 1-23.

21. Trivedi MK, Patil S, Tallapragada RM (2013) Effect of biofield treatment on the physical and thermal characteristics of Silicon, Tin and Lead powders. J Material Sci Eng 2:125.

22. Trivedi MK, Branton A, Trivedi D, Nayak G, Panda P, (2016) Determination of isotopic abundance of $13 \mathrm{C} / 12 \mathrm{C}$ or $2 \mathrm{H} / 1 \mathrm{H}$ and $18 \mathrm{O} / 16 \mathrm{O}$ in biofield energy treated 1-chloro-3-nitrobenzene (3-CNB) using gas chromatography-mass spectrometry. Science Journal of Analytical Chemistry 4: 42-51.

23. Trivedi MK, Patil S, Tallapragada RM (2013) Effect of bio field treatment on the physical and thermal characteristics of vanadium pentoxide powders. J Material Sci Eng S 11:001.

24. Trivedi MK, Nayak G, Patil S, Tallapragada RM, Mishra R (2015) Influence of biofield treatment on physicochemical properties of hydroxyethyl cellulose and hydroxypropyl cellulose. J Mol Pharm Org Process Res 3: 126.

25. Trivedi MK, Branton A, Trivedi D, Nayak G, Shettigar H, Gangwar M, Jana $S$ (2015) Antibiogram of multidrug-resistant isolates of Pseudomonas aeruginosa after biofield treatment. J Infect Dis Ther 3: 244.

26. Trivedi MK, Patil S, Shettigar H, Mondal SC, Jana S (2015) The potential impact of biofield treatment on human brain tumor cells: A time-lapse video microscopy. J Integr Oncol 4: 141.

27. Trivedi MK, Branton A, Trivedi D, Nayak G, Gangwar M, Jana S (2015) Agronomic characteristics, growth analysis, and yield response of biofield treated mustard, cowpea, horse gram, and groundnuts. International Journal of Genetics and Genomics 3: 74-80.

28. Branton A, Jana S (2017) The use of novel and unique biofield energy healing treatment for the improvement of poorly bioavailable compound, berberine in male Sprague Dawley rats. American Journal of Clinical and Experimental Medicine 5: 138-144.

29. Branton A, Jana S (2017) Effect of The biofield energy healing treatment on the pharmacokinetics of 25-hydroxyvitamin $D_{3}\left[25(\mathrm{OH}) D_{3}\right]$ in rats after a single oral dose of vitamin $D_{3}$. American Journal of Pharmacology and Phytotherapy 2: 11-18.

30. Trivedi MK, Branton A, Trivedi D, Nayak G, Sethi KK, (2016) Determination of isotopic abundance ratio of biofield energy treated 1,4-dichlorobenzene using gas chromatography-mass spectrometry (GC-MS). Modern Chemistry 4: 30-37.

31. Trivedi MK, Branton A, Trivedi D, Nayak G, Panda P, et al. (2016) Gas chromatography-mass spectrometric analysis of isotopic abundance of ${ }^{13} \mathrm{C}$ ${ }^{2} \mathrm{H}$, and ${ }^{18} \mathrm{O}$ in biofield energy treated p-tertiary butylphenol (PTBP). American Journal of Chemical Engineering 4: 78-86.

32. Schellekens RC, Stellaard F, Woerdenbag HJ, Frijlink HW, Kosterink JG (2011) Applications of stable isotopes in clinical pharmacology. $\mathrm{Br} \mathrm{J} \mathrm{Clin}$ Pharmacol 72: 879-897.

33. Muccio Z, Jackson GP (2009) Isotope ratio mass spectrometry. Analyst 134 213-222.

34. Weisel CP, Park S, Pyo H, Mohan K, Witz G (2003) Use of stable isotopically labeled benzene to evaluate environmental exposures. J Expo Anal Environ Epidemiol 13: 393-402.

35. Rosman KJR, Taylor PDP (1998) Isotopic compositions of the elements 1997 (Technical Report). Pure Appl Chem 70: 217-235. 
Citation: Trivedi MK, Branton A, Trivedi D, Jana S. The Isotopic Abundance Ratio of Consciousness Energy Treated L-Tryptophan Using LC-MS Spectrometry. J Nutri Health. 2021;7(1): 05.

ISSN: $2469-4185$

36. Smith RM (2004) Understanding Mass Spectra: A Basic Approach, Second Edition, John Wiley \& Sons, Inc.

37. Jürgen H (2004) Gross Mass Spectrometry: A Textbook (2ndEdn) Springer: Berlin.
38. Jiang P, Dai W, Yan S, Chen Z, Xu R, et al. (2011) Potential biomarkers in the urine of myocardial infarction rats: A metabolomic method and its application. Mol Biosyst 7: 824-831.

\section{Acknowledgements}

The authors are grateful to Sophisticated Instrumentation Centre for Applied Research \& Testing (SICART) India, Trivedi Science, Trivedi Global, Inc., and Trivedi Master Wellness for their assistance and support during this work. 